\title{
eCommons@AKU
}

September 2007

\section{Continuing teacher professional development in post-Soviet Kyrgyzstan}

Rahat Joldoshalieva

Aga Khan University, Institute for Educational Development, Karachi

Follow this and additional works at: http://ecommons.aku.edu/pakistan_ied_pdck

\section{Recommended Citation}

Joldoshalieva, R. (2007). Continuing teacher professional development in post-Soviet Kyrgyzstan. Journal of In-service Education, $33(3), 287-300$. 
This article was downloaded by: [INASP - Pakistan (PERI)]

On: 11 September 2012, At: 03:44

Publisher: Routledge

Informa Ltd Registered in England and Wales Registered Number: 1072954 Registered

office: Mortimer House, 37-41 Mortimer Street, London W1T 3J H, UK

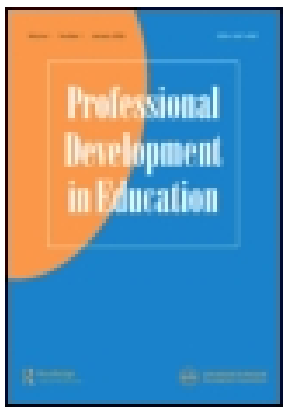

\section{J ournal of In-Service Education}

Publication details, including instructions for authors and subscription information:

http:// www. tandfonline.com/loi/ rjie19

\section{Continuing teacher professional development in post-Soviet Kyrgyzstan}

Rahat J oldoshalieva ${ }^{a}$

${ }^{a}$ Aga Khan University, Pakistan

Version of record first published: 09 Aug 2007.

To cite this article: Rahat J oldoshalieva (2007): Continuing teacher professional development in post-Soviet Kyrgyzstan, J ournal of In-Service Education, 33:3, 287-300

To link to this article: http:// dx.doi.org/ 10.1080/ 13674580701487042

\section{PLEASE SCROLL DOWN FOR ARTICLE}

Full terms and conditions of use: http://www.tandfonline.com/page/terms-andconditions

This article may be used for research, teaching, and private study purposes. Any substantial or systematic reproduction, redistribution, reselling, loan, sub-licensing, systematic supply, or distribution in any form to anyone is expressly forbidden.

The publisher does not give any warranty express or implied or make any representation that the contents will be complete or accurate or up to date. The accuracy of any instructions, formulae, and drug doses should be independently verified with primary sources. The publisher shall not be liable for any loss, actions, claims, proceedings, demand, or costs or damages whatsoever or howsoever caused arising directly or indirectly in connection with or arising out of the use of this material. 


\title{
Continuing teacher professional development in post-Soviet Kyrgyzstan
}

\author{
Rahat Joldoshalieva* \\ Aga Khan University, Pakistan
}

\begin{abstract}
After the collapse of the USSR, Kyrgyzstan became an independent Central Asian state in 1991. Since its independence, there have been enormous changes in the political, social and economic life of the young state, which strives to become a democratic and aspiring market-oriented economy. Its education system has also begun experiencing changes. However, most of the reforms brought in this area continue to be short-term and ever-changing. Economic hardship does not allow the continuation of the previously state-funded teacher retraining system, which further creates deteriorating quality education in the schools. On one hand, the country continues to follow the Soviet in-service teacher education system and procedures that became hard to accomplish. On the other hand, 'lip service' reforms continue to irritate teachers who are left in uncertainty and despair. This paper examines the existing continuing teacher professional development programs in post-Soviet Kyrgyzstan and identifies related issues of quality, access and lack of structure. These all reflect the overall economic decline of the region, which is one of the impoverished Central Asian states. It brings out the necessity for more teacher needs-based programs and the acknowledgement that teacher self-initiated programs/approaches to professional development are necessary.
\end{abstract}

A teacher is one as long as he or she keeps learning. As soon as he or she stops learning, the teacher in him or her dies. (K. D. Ushinski, cited by Kibardina, 1997, p. 15)

\section{Background}

Continuing teacher professional development was an important aspect of Soviet education as Ushinski, the Soviet educationist, stated above. Conceptualized as retraining and qualification raising (perepodgotovka $i$ povyshenie kvalifikatsii), inservice teacher education programs in the Soviet Kyrgyz Republic were systematically implemented through the state-funded Kyrgyz Institute of Education and other teacher re-training institutes in the oblast (provinces). In-service training courses both on-site and off-site were of different durations and varied from full time to part time

\footnotetext{
*Aga Khan University-Institute for Educational Development, 1-5/B-VII, F.B. Area, Karimabad, PO Box 13688, Karachi 75950, Pakistan. Email: rahat.joldoshalieva@aku.edu
} 
and from ongoing, problem-based and goal-oriented to thematic. Additionally, other seminars, theoretical and practical conferences, research experiments, consultative meetings and competitions, such as the Best Teacher of the Year, were part of professional development programs. But since the 1960s the dominant practice for teacher professional development was the off-site one-month course (Kibardina, 1997). It was a requirement that all teachers, after five years of service, attended monthly courses in the central and Oblast Education department. Continuing teacher professional development was also monitored and supported by city and district education departments under the supervision of the oblast Education Department.

Under the Soviet Union, one-half of the content of off-site courses was devoted to ideological and political education where Marxist-Leninist ideology and Communist Party achievements were emphasized. This was because school teachers had the mandate to educate the 'Soviet citizen'. The other half concentrated on specific subject-content and the development of pedagogy and introducing educational innovations (Kibardina, 1997). The pedagogy of these courses was lectures, discussions and problem situations. Kerr (1991) criticizes USSR teacher re-training:

... the opportunities teachers had were in fact quite limited: A few days a year spent in a state Institute for Teacher Improvement (Institut Usovershenstvovania Uchitelei), an Institute for Qualification Raising (Institut povysheniia kvalifikatsii) ... The faculty at these institutes were not (in general; there were exceptions) highly regarded by teachers, and the material they learned there often was not seen as very relevant to their daily concerns on the job. (p. 5)

In post-Soviet Kyrgyzstan, scholars such as Kibardina (1997) and Babaev (1994) have studied different teacher re-training program components. However, since these have been published in Russian and Kyrgyz, to many outsider-researchers this area appears unresearched. Highlighting the issues of in-service teacher education practices in post-Soviet Kyrgyzstan, Kibardina (1997) explains that teacher professional development continues to be the responsibility of the Kyrgyz Institute of Education, Oblast Teacher Retraining Institutes (OTRI), in collaboration with the city and district education departments but, since independence, other institutions offer professional development opportunities for teachers, expanding the limited choices of the Soviet era.

However, foremost, the disintegration of the USSR has negatively affected teachers' professional development opportunities because of the country's general economic decline. Training has become irregular and, because teachers are now required to share some of the costs, such as transport and accommodation, courses are not affordable for teachers. According to the Open Society Institute Education Support Program report, 'Professional support and recognition of teachers decreased as the state failed to fulfill their legal obligations to provide regular in-service training' (2002, p. 17).

Currently, imbalances and shortages of teachers in many subjects in rural locations are catastrophic. Difficult living conditions and irregular payment of salaries mean that rural schools do not attract fresh university graduates. To address teacher shortages, schools have begun using correspondence courses and/or part-time university 
students, retired teachers and recruits directly from schools. However, by recruiting unqualified teachers the quality of teacher performance has also deteriorated. This situation has emphasized the need for serious consideration of diversifying in-service teacher education to meet these contextual needs within the realities of tight budgets.

A small-scale exploratory study was conducted to investigate the existing realities of in-service teacher education in post-Soviet Kyrgyzstan by capturing the voices of serving teachers, of their management and of teacher educators. To do so, I employed semi-structured interviews with 27 individuals, school principals and subject teachers from four city schools ${ }^{1}$ and teacher educators from the OTRI and city education department master trainers in Osh oblast, southern Kyrgyzstan. Data were collected between December 2003 and January 2004. In addition, I observed some teacher professional development activities at schools, sessions at teacher retraining institutes and a city teachers' conference. Since all the data were collected from city schools, the findings and discussion excludes the realities of in-service teacher education in the rural schools.

\section{Findings}

Existing continuing teacher professional development

With the exception of the new opportunities provided by organizations other than government, the structures and activities for teachers' professional development reflected those of Soviet in-service teacher education. Three main approaches (off-site courses, school-based and self-initiated activities) co-exist and supplement each other in continuing teacher professional development programs in post-Soviet Kyrgyzstan.

Off-site courses included courses run by government OTRI but, in addition, the city education department, in collaboration with Kyrgyz Institute of Education, organized annual 'January' and 'August' conferences.

The following observation was noted in a technical drawing teachers' subject meeting during the January conference.

The session started with a school teacher presenting her report on didactic methods of teaching this subject. This was followed by a city education department methodologist who informed teachers about the upcoming inspection from the Ministry of Education from Bishkek and gave a list of required documents to file. He dictated that calendar plans should be complete and neatly done, teacher resumes (CV) and plan of club activities, monitoring and analysis of children's learning of subject, classroom decorations, and notebook on self-education and teacher reports. Teachers requested an explanation of what 'resume' meant. Head of this subject department for city schools shared the structure of the resume. Teachers further shared the concerns over lack of own classrooms for decoration and other resources. The methodologist further ordered teachers to share the classrooms with other subject areas and decorate and find resources for documentation and decoration. He stated, 'Your students don't know very simplistic skills in technical drawing because quality of teaching is not good'. (January 2004)

Other seminars were offered by international institutions, such as the Soros Foundation Kyrgyzstan. A teacher shared his experience from one of these courses. 
I have attended the course on Yiman [moral education] in falal Abad city. This subject is newly introduced to schools. The course was conducted by some Americans and our own educators. It was an interesting course as they used many interactive methods. I am now trying to implement the ideas in my teaching. (Primary class teacher, school G)

Geopolitical interests in the region were also reflected in in-service teacher education as some courses were funded by countries with political interests. The Russian Federation funded programs that offered short-term courses for Russian medium school teachers at one of the universities of Kyrgyzstan. For Russia, it was strategic to support Russian language instruction in post-Soviet Kyrgyzstan where Russian was recognized as an official language.

School-based activities included subject methodology, mentoring beginning teachers and induction seminars for beginning teachers. Subject methodology was based on departments of specific subject teachers, headed by an experienced colleague. A head of an English language department explained this process in the government school:

In our English language department we have one theme for each month and assign the teachers. They plan and conduct the seminar for others. We discuss the issues and suggest ways to improve the teaching of English language at school. Each class unit is also divided into 9 parts and we usually discuss those with each other. Apart from this, experienced teachers observe and help beginning teachers. Each methodological department is responsible for dekada in their subject areas. There are 9 subject areas for 9 months. (English language teacher, school G)

Dekada was usually of 10 days duration. This activity was initiated by the city education department subject area components to support teachers of core subjects prepare a plan of activities so that all city subject teachers should have professional development activities in one particular school. The set of activities included lesson-demonstration and co-curricular activities such as drama and quiz competitions. After observing different lessons and activities, teachers analyzed and raised issues and teachers are encouraged to share innovative ideas and discuss related issues. The vice-principal monitors the department's activities. Within schools, subject departments organize subject seminars at different times of the year. The teachers leading the event prepare curriculum-related activities related to the subject area and then a forum for joint discussion on observed lessons and on general issues of teaching.

In three schools, experienced teachers mentored beginning teachers. Many young teachers reported that mentoring enabled them to learn classroom management skills. A teacher had the following to say:

Each beginning teacher is supposed to work with an experienced one. Mostly mentoring is conducted through encouraging beginning teachers to observe an experienced teacher's lessons. (English language teacher, school G)

Apart from mentoring, newly recruited teachers attended induction seminars organized by the school. They had most difficulty with school documentation, such as lesson planning and maintaining the class register. A vice principal of academics explained further: 
The fact is that $25 \%$ of our teaching staff consists of beginning teachers this year. In December, we are planning to conduct a seminar for newly recruited and beginning teachers on 'Help for young teachers'. Experienced teachers will share their experiences with them and demonstrate some good teaching practices. They will also learn how to fill the class register and deal with other school documents. (Vice principal, school G)

In one of the private schools, seminars for newly recruited teachers were organized systematically with comprehensive syllabus and curriculum development exercises to encourage them to use learner-centered approaches and designed to acquaint them with the nuances of the private school system. It was emphasized that:

In our school, we emphasize teacher professional development. So we create conditions for this. First of all, we have a special position of teacher educator who is responsible for planning and carrying out professional development activities. The person has the qualifications required and a rich experience of conducting professional development. She prepares an annual plan for teacher development, which we discuss and amend according to our needs. Secondly, we have arranged one day for professional development that is Saturday. This day is used for seminars or courses or teacher independent development. Thirdly, we have funding for organizing seminars and inviting qualified specialists for this purpose. (Principal, school A)

In one government school, a newly-created position of vice-principal is equivalent to an in-house teacher educator who was expected to plan professional development programs for teachers. This was the first post of this kind.

Another form of professional development is teacher appraisal, which usually requires compulsory demonstration lessons. In addition, the city education department requires teachers to maintain a portfolio to demonstrate their involvement in continuing professional development, which could include evidence of their improved pedagogical skills, participation in teacher development courses and workshops, up-to-date knowledge about political events in Kyrgyzstan and teachers' involvement in curriculum-related activities within and outside school. Moreover, each teacher was required to observe other colleagues' lessons and record those in their peer-observation journals. School-based teacher professional development was considered useful in many respects, since it allowed teachers to learn specific aspects of teaching and utilized school resources such as time and fellow teachers effectively.

There were examples of diverse forms of self-initiated teacher development. Teachers reported that they looked for opportunities outside school to develop professionally. As one teacher said:

During Soviet times, the government directed teachers to attend courses. Everything was paid by the government. Nowadays, we are looking for the courses and pay for them ourselves. (Kyrgyz language teacher, school G)

Among many other opportunities, teachers attended seminars organized by the Soros Foundation Kyrgyzstan and award-bearing courses or short-term programs created a path for teachers to get experience of training outside the country. However, many of these were restricted to teachers who had mastered the particular foreign languages (predominantly English). Unfortunately, for this reason, many teachers could not avail themselves of such opportunities. 
Teachers also consulted colleagues from other schools and/or university faculty to learn more.

I consult the teacher in $\mathrm{X}$ school who taught me mathematics if I have some problems in some aspects of teaching or the content itself. Even when I had some problems regarding the calendar planning, I went to her as she was very experienced teacher and soon she would retire. I go to her because there is nobody who could help me in my area at our school. I also phone my friend who teaches maths in another school. We share our experiences and new methods. We cannot meet often as I am busy at school till 4 in the afternoon every day. (Mathematics teacher, school I)

Likewise, committed teachers organized workshops for colleagues to share what they had learnt from courses or from implementing ideas in their classrooms. However, they indicated that they got de-motivated when their colleagues showed little interest to attend and did not appreciate their effort.

Teachers' own individual and independent work in enriching or developing their own syllabus also created opportunities for teachers to learn more. Teachers introduced changes and enriched the syllabus within the limits of school and classroom realities and to suit students' diverse needs and styles of learning. Teachers were also encouraged to disseminate their tested curriculum to other teachers by publishing in newspapers:

Nowadays all the teachers in government schools have the chance to develop their own curriculum. They also can disseminate to others if they can. For instance, I have developed my own curriculum for primary classes and I am expecting it to be published soon. I want to note that we can develop ourselves in this way too, but it depends on ourselves as teachers whether we are willing to work hard on those as it requires commitment and will. If we work hard, we can achieve many things. (Primary class teacher, school G)

Teachers read literature subscribed to by the school or themselves or accessed them in oblast libraries to enrich their content and delivery. The national educational newspaper from the Ministry of Education, Kut Bilim, periodically published newly required documents for schools and teachers, and thus further increased their knowledge of the wider educational context. Hence, as the Bekbolotov report (1999) stated that, despite the hardships, teachers in Kyrgyzstan continue to improve their professional skills independently or to gain experience from each other's practices.

\section{Issues with existing teacher professional development programs and structures}

The most criticism regarding continuing teacher professional development programs related to low quality, the difficulty of access and the lack of supportive structures.

\section{Deteriorating quality}

Teachers were highly concerned about the deteriorating quality of teacher professional development in terms of content and pedagogy, structure and relevance. Most criticism was related to the OTRI programs and was of outdated, purely theoretical 
course content and authoritarian pedagogy; the insensitivity towards teachers' needs; and teacher trainers' poor professional expertise. Due to its poor quality of teacher training, OTRI did not seem to attract private schoolteachers to attend their programs:

The courses in the Oblast Teacher Retraining Institute did not offer much support to my teaching. I just spent one month without any improvement. Although, I got theory in general, I did not learn anything new specifically about my subject area. (Mathematics teacher, school I)

In the past, teacher trainers were expected to have classroom teaching experiences so that they could work with school teachers. In this regard, some OTRI teacher trainers were critical about their colleagues who had no classroom teaching at schools. In addition, unsatisfactory salaries and the lack of a supportive structure in the institute did not motivate them to develop professionally and the institute failed to recruit highly qualified professionals because of underfunding.

A heavy emphasis on nation-building after independence has, to some extent, resulted in creating feelings of insecurity in ethnicities, such as Russians, in Kyrgyzstan. The educators who occupied most positions at the universities and other institutions were replaced by non-Russians, and courses were often criticized because of the poor Russian language proficiency of the trainers.

City education departments did not restrict private schoolteachers' attendance in the annual subject dekadas in January and August. However, school management did not consider that it would be beneficial to attend:

\begin{abstract}
All of our teachers previously worked in government schools and attended these dekadas and other gatherings. We know the process well and I did not benefit to any great extent from them. Except for the dissemination of information, there is usually nothing there. They could disseminate the information in other ways to tell the truth. In addition, in these subject section or department activities, nothing is resolved or decided or worked. (Vice principal, school I)
\end{abstract}

Within school-based teacher professional development, mentoring was considered beneficial for mentor and mentee teacher. But because of financial restraints, mentoring was not as systematic and regular a practice compared with Soviet times and its quality worsened due to several factors. Firstly, teachers' heavy workload did not allow them to spend time to observe lessons and discuss them with mentees. Thus, with little support, mentee teachers struggled with school and classroom difficulties on their own. Secondly, because there were fewer experienced teachers in the schools, teachers with only two years' experience were expected to mentor new teachers; thus, in many respects, both were inexperienced. So the quality and authenticity of mentoring was questioned.

In one instance the heavy content of a school-based course in a private school was questioned as to its impact on teachers' classroom teaching. Providing support for application in the classroom was overlooked in an ambitious attempt to change teachers' conceptions. Moreover, the generic nature of seminars on teaching methods did not help teachers to implement them in specific subject areas. 
In relation to the value of discussing professional literature, teachers' concerns were associated with its inappropriateness to their specific needs and contextual realities. However, teachers realized that the value of their own experience should be extended and that they should take responsibility to disseminate that knowledge to other teachers. Unfortunately, directly or indirectly, the worsening quality of programs or activities reflected the overall economic crisis of the country and shrinking state funding on public education.

\section{Access as an issue}

However, the deteriorating situation of teacher professional development in postSoviet Kyrgyzstan was also associated with the lack of access to professional literature and quality teacher professional development programs. To sustain and raise the quality of courses at OTRI, teacher trainers required access to quality professional literature and supportive information technology. They explained that the problem of outdated content was due to the institute's inability to find financial means to supply up-to-date literature and equipment. Trainers had to continue to use the resources they had inherited from the Soviet era, which could not satisfy modern requirements.

Teachers of core curricular subject areas (mathematics, languages and history) had wider options to participate in courses and this generated disappointment in teachers of subjects considered less important, such as physical education and music.

The collaboration between government and private institutions also required considerable attention in a situation where a private sector was emerging in a previously public sector dominated society. The lack of structures for collaboration seemed to create the major issues and tensions. Private-school teachers felt there was unfair treatment when special training was provided for government teachers and they were excluded from the opportunity or met demands for them to pay for participation in the programs. With a tight budget, the needs of government institutions, which served the wider population, became the priority for the state.

Teachers emphasized that the lack of access to professional literature was the major challenge. Given the low-paid profession, teachers cannot afford the luxury of subscribing to professional literature as compared with the plentiful access of Soviet times. In addition, the prices for literature and periodicals have risen considerably with the emergence of a free market. Government schools subscribed to few periodicals from their budgets and sometimes deducted a contribution from teachers' already small salaries. Many teachers complained of being forced to subscribe to journals when they could not afford to feed their family on their salary.

Sometimes the Soros Foundation gives us some literature, but they are so few. For instance, last year we got one edition of journal 'Forum' and a single copy. We used to subscribe to 'Foreign languages at schools' during the Soviet Union, almost every foreign language teacher could do this. But now each edition is 200-300 Kyrgyz soms, ${ }^{2}$ we cannot afford that. (English language teacher, school K) 
Few and intermittent issues, and mostly of low-quality literature, do not solve teachers' need to learn new content and pedagogy. Some teachers were even of the opinion that Kyrgyzstan was isolated from information especially in the Russian language. Furthermore, teachers of subjects newly introduced into the curriculum echoed that they did not get subject-area methodological literature. For instance, the Kyrgyz language gained official language status and became a compulsory subject at non-Kyrgyz medium schools. Teachers complained about the lack of specific pedagogy and articles related to teaching and learning the Kyrgyz language in these schools. Although some organizations continued to supply some of their periodicals, schools considered these as 'gifts' and considered there was a need to have a countrywide thoroughly systematic process of subscriptions to professional literature in the future. Professional literature produced outside Kyrgyzstan was largely inaccessible.

Teachers felt that, in Kyrgyzstan, access to professional literature was at a critical stage.

Teachers need to actively subscribe to professional publications and journals. It is at least encouraging that Mektep, a professional journal, has started to be produced in Kyrgyzstan. We could look at the Russian publications and come up with similar or contextually relevant outlines for the publications. And if there is any foundation to support the people who can come together for this purpose, it will be so good for teachers to receive the information. I feel that schools should take this idea seriously. They can collect samples of good lessons. It is very important to note that it would encourage sharing experiences which unfortunately is not happening to greater extent. (Vice principal, school I)

Other initiatives were suggested to encourage publications on professional innovations and ideas and that it was important to consider involving the private sector in publication. However, many felt that, with the growing community of Internet users, teachers could develop professionally by accessing web-based materials and not only depend on printed material. But since there was little available in Russian on the Internet, which was dominated by English sources, teachers could not use this opportunity to any great extent.

\section{Lack of supporting structures for teacher professional development}

School structures, such as provision of time for professional development, reasonable teacher salaries and support in providing programs for development and creating teacher networks, were not well-thought through in in-service teacher education systems in post-Soviet Kyrgyzstan. Lack of recognition of their hard work affected teachers' low motivation to develop professionally. In this, one of the sources for motivation - teachers' salaries - played an influential role.

First of all, teachers need to be motivated through an increase in salary as an incentive to develop professionally. When you don't have bread to feed your children at home for the salary you get at school, how will you think of developing professionally? (Primary class teacher, school G)

Government school teachers did not have time for their professional development because of heavy teaching workloads to increase their income: 
We also want to teach fewer classes and develop ourselves. But I have to feed my children and help to support the family. Because of this, we teach more classes because in that way we can earn more. (Russian language teacher, school K)

It was suggested that teachers' salaries could be differentiated not only by experience but also by evidence of original and creative ways of teaching and learning.

In Kyrgyzstan, with the exception of the English language teachers' association, there are no teacher associations.

I would like a teachers' centre to be organized so that teachers could share their experiences and discuss issues of teaching and learning with each other. The centre would make these more systematic as we as individual teachers find difficulty to go to each other and discuss issues. (Mathematics teacher, school I)

Teachers identified the need for teachers to form teacher associations to bring subject teachers together and enable them to learn from each other. They were willing to be proactive in establishing associations in order to establish teacher networks.

For teacher professional development we have only one institution as a single institution of this kind in the oblast. Teachers need to solve this problem themselves, I think. It can be as an NGO type of organization or association. I talk to university faculty; they have good knowledge, information and innovative teaching strategies to share. I think they should come together with school teachers to form an association to have a forum to share their experiences and knowledge. Another option is to have Internet online discussion forums ... (Vice principal, school I)

Teacher networks could help teachers to work together for improvement and to voice their collective concerns at a time when they are vulnerable from rapid changes in their personal and professional lives'

\section{Discussion of findings}

The aftermath of the collapse of the USSR and independence has not brought positive effects on the professional lives of the teachers of Kyrgyzstan. It has resulted in uncertainties and increased responsibilities rather than the hope of support for teachers. Teachers identified the need for their professional development as urgent because the goals of education have been changed. As Mertaugh (2004) observed, 'The content and delivery of education needed to be changed in order to make education responsive to the needs of the global economy' (p. 155).

Post-Soviet Kyrgyzstan in-service teacher education practices and policies largely reflected the Soviet ones. However, the issues raised here require the critical attention of education policy-makers. For instance, the idea that the so-called reforms would improve teacher performance mostly lacked empirical evidence. For the most part, teachers' professional development activities did not take into account teachers' needs and thus did not directly respond to teachers' classroom realities. Moreover, the courses also devalued teachers' existing expertise. As Niyozov (2004) noted, 'They [teachers in Tajikistan] are subjected to top-down approaches and outside-in training, where their knowledge and wisdom are largely ignored' (p. 57). Some grand projects were implemented without much consideration and discussion. With this 
regard, DeYoung (2004) shared the argument around an Asian Development Bankfunded 'distance learning' center initiative that was negotiated between the former education minister and the Bank during the mid-1990s. The origin of policies might be better explained by the fact that they met vested interests and needs for power rather than real and practical needs. DeYoung stated:

Much of the work was contracted or coordinated by one of the national universities that a former Deputy Minister of Education was now the rector of, and other universities were to provide program staff (if and when there was money for them). (2004, p. 214)

He continues pointing out some issues that were raised regarding the budget of the program that allocated little for program staffs and lack of formal job descriptions for the staff.

Research continues to demonstrate that programs based on teachers' needs make more impact on teachers' professionalism in practical terms. In this respect, the OTRI diagnostic questionnaire of teachers' needs is an excellent idea but it should be further improved to make the training relevant to teachers. The courses funded by other groups should be carefully analyzed. A report of the Open Society Institute Education Support Program (2002) highlighted this, stating:

\footnotetext{
With the increased presence of donor assistance, and co-operating partners who have their own intentions and interests around the in-service training of teachers, it is important to coordinate activities. Any activities in the field of teacher training should be based on the demands and needs of strategic reform and the overall system. (p. 23)
}

In future reforms, the importance of the 50 years' experience of OTRI should be taken into account so that the strategies they used can be improved within the realities of present conditions rather than ignoring it. For example, the existing structure of seminars should be further improved and reforms should target similar activities to make teacher professional development programs more practical and needs-based. The January and August conferences are cost-effective and could remain a credible approach, although methods of delivery and content should be extensively discussed further. Currently, teacher trainers' own development seems to be taken for granted. But the personnel are ageing (Bekbolotov, 1999; Open Society Institute Education Support Program, 2002) and, as Kabylov (2003) says, 'There is a considerable need for continuing training for the teacher educators themselves' ( $p .5$ ) so that they can offer quality training.

In post-Soviet Kyrgyzstan, off-site in-service teacher education courses continue to be seen as the panacea for low-quality schools and the means of school improvement. But all the training emphasized the development of teachers' technical skills and not developing their reflective teaching ability. The possibility of practice-centered approaches for teacher development did not usually get the attention of policymakers. Also, the policies and reforms to promote school improvement and teacher education largely ignored existing self-initiated and school-based teacher development activities. Yet, it must be emphasized that all these activities and their structures require considerable attention to their reform in the light of current realities and priorities. Practice-centered approaches to teachers' professional development, such 
as action research and reflective practice, remain unknown and are not part of the current practice of in-service teacher education. In addition, school-based teacher development was not monitored and evaluated formatively. Where this was part of management responsibilities the approach was critical rather than supportive. Also, where schools cannot provide the time or resources to support professional development and an in-house teacher educator, they are unlikely to be able to expect much from teachers.

Additionally, meager teacher salaries have resulted in low social status and low motivation for teachers. Mertaugh (2004) points out that teacher salaries are low in both absolute and relative terms.

In absolute terms, they are only half of the minimum consumption level for individuals, not to mention households. As a result, teachers lack motivation and are compelled to work at other jobs in order to support themselves and their families. (p. 173)

Similarly, Niyozov (2001) emphasized the proposal of Marx and Maslow that, 'when basic human needs are threatened, talk about intellect and education makes little sense' (p. 363). Thus this basic need forces teachers to find other solutions. As Shamatov (2005) stated: 'Teachers also have to supplement their income by taking up extra work in order to fulfill their material needs, many teach in more than one school' (p. 116).

Raising teachers' salaries and providing fringe benefits such as releasing them from paying electricity bills were considered important to retain teachers and to motivate them for professional development. Mertaugh (2004) suggested comparisons with the health service, which has introduced several reforms to raise the salary of health workers, and suggested that 'activities such as mentoring new teachers or providing community education or remedial education could and should be recognized and compensated through supplementary income' (p. 173). However, although raising salaries could motivate teachers to develop professionally, it would not affect the quality of teaching and teacher professional development substantially if supportive systems for professional development were not considered as well as systematically implemented and monitored. Thus, improving the existing supportive systems and establishing monitoring and evaluation must be part of the reforms.

Currently, too, school teachers in Kyrgyzstan cannot access professional literature as sources for their professional development. The Bekbolotov report (1999) claimed that information related to modern teaching methods was unavailable and that low salaries made access to professional literature impossible for individual teachers. To continue the Soviet practice of making subscriptions mandatory is, under present circumstances, a burden not a solution. Many teachers resented this practice when their salary was not enough to feed their families let alone buy and read the newspapers. An open letter, voicing teachers' concerns, to the president and minister of education, has resulted in stopping these compulsory subscriptions.

At the moment, teachers in post-Soviet Kyrgyzstan seem to be caught in a dilemma. On the one hand is their struggle for personal survival as a priority. On the other hand is their mission, as professionals, to educate the next generation better for 
the good of society, which makes them continue to work within harsh conditions. Many government teachers felt isolated and abandoned by the state. I found teachers who looked for external help but there were some who thought this was not a solution. Rather, they recognized their proactive role in solving their professional issues themselves or by making a considerable contribution. For example, teachers proposed teaching materials developed and tested by teachers to support them in the 'methodological vacuum' and teacher networks with the potential to support and enable teachers to contribute to building a more just, fair and equitable society after this transition period.

\section{Conclusion}

The demand for continuing professional development that is foremost in post-Soviet Kyrgyzstan comes from the desire to raise the quality of education and the emphasis on a democratic way of life that is spreading throughout Kyrgyzstan. It is reflected in schools and it confronts previously authoritarian teaching. Yet in the decisions over what reform to adopt and how, the voices of serving teachers, their expertise and their approaches to innovation were largely ignored. This has brought token approaches, not genuine reforms, in in-service teacher education. Therefore, in the future, teachers' self-initiated and school-based professional development require better consideration and recognition by the education policy-makers and strategies to improve them further. In-service teacher education could be enabled to be more diversified and more related to the professional discussion and immediate translation and dissemination of local knowledge about pedagogy and content, which teachers felt acutely was the only solution to the vacuum of professional information. Ironically, despite their meager salary and lower social status, I found teachers still motivated for further development because of their optimism for the future betterment of their country.

\section{Notes}

1. Two schools were newly opened private schools - one locally owned and the other by an education agency. The other two schools were government gymnasium schools.

2. Approximately US $\$ 5-6$.

\section{References}

Babaev, D. (1994) Didakticheskyie osnovy profetsionalnogo stanovlenia uchitelia fiziki v protsesse nepreryvnogo obrazovania. Unpublished Doctor of Pedagogical Sciences dissertation, Academy of Sciences, Bishkek.

Bekbolotov, T. B. (1999) Kyrgyz Republic country report on education for all (Bishkek, Ministry of Education, Science and Culture). Available online at: http://www2.unesco.org/wef/countryreports/kyrgyz/contents.html (accessed 10 October 2003).

DeYoung, A. (2004) On the current demise of the 'Action plan' for Kyrgyz education reform: a case study, in: S. Heyneman \& A. DeYoung (Eds) The challenge of education in Central Asia (Greenwich, CT, Information Age Publishing), 199-224. 
Kabylov, T. (2003) Issues of government-based in-service teacher education programmes in Kyrgyzstan: what is needed for improvement?, paper presented at the CESS 4th Annual Conference, Harvard, MA.

Kibardina, L. P. (1997) Protsess obuchenia v sisteme povyshenia kvalifikatsii pedagogov Kyrgyzskoi Respubliki (Bishkek, Kyrgyzstan).

Kerr, S. (1991) Beyond dogma: teacher education in the USSR, Fournal of Teacher Education, 42(5), 332-349.

Mertaugh, M. (2004) Education in Central Asia, with particular reference to the Kyrgyz Republic, in: S. Heyneman \& A. DeYoung (Eds) The challenge of education in Central Asia (Greenwich, CT, Information Age Publishing), 153-180.

Niyozov, S. (2001) Understanding teaching in post-Soviet, rural, mountainous Tajikistan: case studies of teachers' life and work. Unpublished doctoral thesis, University of Toronto, ON.

Niyozov, S. (2004) The effects of the collapse of the USSR on teachers' lives and work in Tajikistan, in: S. Heyneman \& A. DeYoung (Eds) The challenge of education in Central Asia (Greenwich, CT, Information Age Publishing), 37-64.

Open Society Institute Education Support Program (2002) Education development in Kyrgyzstan, Tajikistan and Uzbekistan: challenges and ways forward. Available online at: http://www.osiedu.net/esp/events/materials/final.doc (accessed 10 May 2003).

Shamatov, D. (2005) Beginning teachers' professional socialization in post-Soviet Kyrgyzstan: challenges and coping strategies. Unpublished doctoral thesis, University of Toronto, ON. 